\title{
Bicultural Identity Negotiation in Beur Cinéma: The Case of film Samba
}

\author{
Wulan Tri Astuti ${ }^{*}$, Faruk ${ }^{2}$, Budi Irawanto ${ }^{3}$ \\ ${ }^{1}$ Media and Cultural Studies, Graduate School of Universitas Gadjah Mada \\ ${ }^{2}$ Faculty of Cultural Sciences, Universitas Gadjah Mada \\ ${ }^{3}$ Faculty of Social and Political Sciences, Universitas Gadjah Mada \\ *wulanastuti@ugm.ac.id
}

\begin{abstract}
This article seeks to fill gaps in the literature on French cinema's treatment of immigration. Previous researches of this theme have tended to position immigrants as objects, individuals perceived as creating problems and as using violence to resolve problems. This article highlighted in French films under a new genre, Beur cinéma, notably in the film Samba (2014) to discuss French cinema's depiction of immigrants' experiences with cultural negotiation mainly their struggle on negotiating identity. Film Samba will be analysed by its cinematographic signs using the theory of cinematographic semiotics. This study finds that what has been understood as the cause of the lack of integration of immigrants is mainly the residence permit is not justified. This article further reveals that migrants' challenges in maintaining their cultural identity also stem from difficulties in adapting to language skills, daily life, and even difficulties in communicating with nearby communities. Faced with all these obstacles, the film Samba concludes that violence cannot be seen as a solution.
\end{abstract}

Keywords: Beur Cinéma, Film, Negotiation, Bicultural, Identity.

\section{INTRODUCTION}

Diaspora conflicts in the destination countries for immigrants, especially France, have become never ending issues. Since the 1960s, filmmakers, particularly those from diaspora communities, have explored and observed the lives of immigrants along with the development of similar films in Britain (the problems of Blacks and Asians), America (the problem of the Iranians, African-Americans, and Asia PacificAmericans), and Canada (conflict with South Asia) [1, p. 39].

Movies on diaspora generally question national and state identities through images. Unlike national movies, these movies can deconstruct and challenge the understanding of hegemonic identities in the real life through a post-colonial point of view [2]. Movies on diaspora can be said to be a political project that depicts the real life of border communities in the post-colonial era. The implicit social inequality, inequalities, and the hardships of marginalized people manage to thrill the viewers.

Xenophobia and racism in France have long been discussed in various works, including in movies. One of the works is a movie by Mathieu Kassovitz entitled ' $\mathrm{La}$ Haine' (1995) and the hit comedy, 'Les Intouchables' which was released in 2011 and later remade by the Escape Artists production house from America with the title 'The Upside' in 2017. Among various movies about immigrants in France, one of the most prominent movies is 'Samba' which was released in 2014. The title was taken from the name of the main character 'Samba' and it was released at the right time with its fresh view on immigrant cultures practiced in France with daily conflicts packaged in the drama-comedy movie, far from the image of violence echoed by the media.

The purpose of this paper is to fill the gaps of the study on the immigrants in French movies which tend to see immigrants as trouble makers who resolve their conflicts with violence. This paper specifically discusses the cultural identity negotiation of immigrants in a French movie, 'Samba'. This paper brings up two questions. The first is how the identity negotiation of the diaspora community is presented in the movie, and the second is how obstacles and solutions to immigrant problems are represented in the movie. These two questions elaborate not only the pattern of relations between the culture and the country of origin of 
immigrants but also the participation of immigrants in the French movie.

France has quite significant number of populations of immigrants that deserve equal attention in every area of life. In the 1980s, a new movie genre emerged in France, namely 'le beur cinema'. Beur is a derivation of the word arabe with verlan or word inversion. Beur in this context is the second or third generation of Maghrebi people or children whose parents are immigrant workers from North Africa and born in France [3, p. 88], [4], [5]. Prior to that year, the first generation of Africans had started making documentaries reflecting the hardships in the suburbs of Lyon and Marseille in the 1960s [6, p. 51]. The rebirth of these movies cannot be separated from the political influence that has suppressed the lives of immigrants with detrimental policies. In the 1980s, immigrants had limited opportunities to appear as main characters in national movies [7], [8]. This fact triggered the directors from the diaspora communities and France to re-initiate movies that made immigrants more prominent from a cultural and political point of view. The cultural integration of immigrants is only possible with the power of the state as a policy maker. In the scope of national borders, the classification of individuals entering and leaving the region within a certain period of time is a crucial indicator. Diaspora communities, according to Laayouni [9, p. 30], are divided into three categories, namely immigrants, naturalized immigrants, and Beur. This categorization can help differentiate viewpoints, characters, and experiences of the first-generation immigrants coming to France as adults, newly arriving elder immigrants, and the Beur group who have settled down from early age. These differences can also be reflected through literary works, such as films, novels, poems, and short stories.

\subsection{Research methodology}

This research emphasizes on the qualitative descriptive analysis and the result will be represented by description. This research is conducted in several steps, firstly, determining the film under the Beur cinéma category to be analysed, a film entitled Samba was chosen because this film deserves attention for its honest restraint yet comic in dealing with issues that are too often neglected until erupting into uncontrollable outrage (violence) both in film and in real life. In this research, film is treated as text, reading is conducted repeatedly, initially reading is for image (scenes, shoots), then it is continued with reading the contents of the dialogues and the setting of scenes. After making observations, is to classify the dialogue or text in the film to see which parts of the film represent the negotiation of bicultural identity. The third step, determining the approach or method of descriptive analysis process of filtered data based on the film semiotics theory. The next analysis is the discussion on the representation of the negotiation of bicultural identities. The dialogue and image analysis will be discussed in the linguistic dimension of filmic facts. This study will view films as text in relation to emphasizing the singularity and totality of their markings which is called the analysis of the film text and emphasizes the theoretical perspective in an effort to explain the mechanisms of meaning production known as cinema language analysis

\section{RESULT AND DISCUSSION}

\subsection{Immigrant Diaspora in The Film}

The diaspora of the French colonies still exist, but not all of them are considered equal [10]. Some ethnic minorities are rarely portrayed as colonized minority colonies as presented in the movies 'Lovers' by JeanMarc Barr (1999), 'Sauve Moi' by Christian Vincent (2000) which depicts the life of immigrants from Southern Europe, 'Swing' by Tony Gatlif (2002) about Italian communities, and 'Welcome' by Phillipe Lioret (2009) about West Asians. The unbalanced proportion of the portrayal between the colonizer and the colonized can be found in contemporary French movies. The ethnic minorities that often appear are Africans, Antilles from the Caribbean, and the Maghreb communities (Algeria, Morocco, and Tunisia).

Beur cinéma manages to represent resistance to society's images of marginalized people. The main issue in dispute was the citizenship status of immigrants. Problems were growing since French society looked at immigrants with contempt so that the practice of acculturation did not work well. From a political perspective, immigrants were recognized as French citizens, but from a social perspective, there was an absence of inter-ethnic tolerance. The government finally implemented the assimilation system as a solution to realize the unity in the French revolution. The assimilation policy forced immigrant communities to reconstruct their cultural identity. This can be seen from the scope of family as the first layer to practice and pass on identity to its members. Migration for a family means leaving the family group from which a person is born to move to another place. This moving on the destination area has resulted the new challenge for the migrant as they have to negotiate between the heritage identity and the new culture that they are facing at the moment, resulting a new bicultural identity for them.

The concept of biculturalism is originated from the studies of acculturation [11], [12]. This concept focuses primarily on cultural behaviours such as language use, choice of friends, media preferences, and the like [13]. In this perspective, individuals are considered bicultural if they speak the language of their heritage or descent culture and the language of their new culture, have friends from both cultural backgrounds, and watch television programs and read magazines from both 
cultures. Several other authors have developed this concept by suggesting that true biculturalism weaves the culture of origin and accepts the new culture into a unique and personal blend. From this perspective, the bicultural individual chooses aspects of the cultural heritage of his/her origin and the new culture and integrates them into the individual 'culture' instead of directly reducing his/her cultural heritage into a new culture [14]. For example, the people of Arab descent in Indonesia may eat traditional Arabic spiced rice, such as biryani or mandi with processed vegetables from young jackfruit, and chili paste that is known as sambel megono. They may speak mixed Indonesian and Arabic and mingle in social groups of friends of Arab and Indonesian descent.

It could be argued that the concept of biculturalism involves more than just cultural behaviour. Schwartz and Unger [15] offer an expanded definition of acculturation that includes cultural practices, values, and identification. Their argument states that a truly bicultural person will mix the culture of his/her origin and accept the flow of culture related to cultural practices, values, and identification. This means that biculturalism does not only mean behaving in accordance with two cultural contexts but also holding the values of one's heritage and accepting the flow of culture as well as identifying oneself with the two cultures.

The source of the data for this study was a 2014 French movie entitled 'Samba' directed by Olivier Nakache and Éric Toledano. This movie was chosen not only because many reviews had discussed this movie which made it become the evidence of recognition from movie critics from both France and other countries, but also because this movie also received recognition from filmmakers with nominations from four festivals, namely the 2016 Black Reel Awards, France's 2015 César Awards, 2015 European Film Awards, and France's 2015 Lumiere Awards. The data were collected using a document analysis technique.

\subsection{Identity Negotiation: Identity is Fluid}

'Samba' was directed by a director duo who has similar identities. Both Nakache and Toledano have the Jewish blood from their parents. The difference is that Nakache's parents are Algerian Jews, while Toledano's parents are Moroccan Jews. Then they both also served as screenwriters of the movie assisted by two other people, Delphine Coulin and Muriel Coulin. The movie was under the supervision of three main producers, namely Nicolas Duval Adassovsky, Laurent Zeitoun, and Yann Zenou and supported by Omar Sy as the coproducer and the main character, Samba. It seems that the backgrounds of the directors and their film-making team as immigrants and/or descendants of immigrants have greatly influenced the story in 'Samba'. This movie represents not only the main character but also several other supporting characters as survivors through identity negotiation.
The title of this movie was taken from the name of a figure who became the central point throughout the story, Samba Cissé. He was an immigrant from Senegal who had illegally lived for almost 10 years in Paris. It was illustrated at the beginning of the story that Samba had a job as a dishwasher at a restaurant in the French capital. Unfortunately, Samba got into trouble after his residence permit was rejected by the immigration office. He was arrested and detained in an illegal immigrant holding camp. After going through the trial process, Samba was obliged to leave French territory, and it would be considered illegal if he still stayed in the country. Meanwhile, his family badly needed him since he routinely sent money to his parents in Senegal. Along the way, Samba then negotiated to stay in France by borrowing other people's identities several times.

The conflicts in 'Samba' are daily life problems presented in in-depth stories about immigrants who struggle to seek for their own position and find their own identity in a foreign culture. Samba, for example, whether he liked it or not, he had to hide his identity and followed various directions given by his uncle to reduce the suspicion of the authorities. On the other hand, he also had to work to survive. For this reason, Samba's uncle gave him his identification card to find work. It was known later that like Samba who used the 'loan' identity card, other immigrants also had the same problem. They used other people's identity cards and residence permits.

Overall, through the main character, Samba who had been in France for almost 10 years provides a reflection on the lives of immigrants. They still have difficulties obtaining residence permits that are very crucial for their daily lives although they have lived for a long time in France. They can then only hide behind fake identities and confirm any name printed on the identity cards they show to the employers. Their jobs are mostly menial jobs with daily wages. While changing jobs every day, they must continue to hide from the police. All of this is done to stay alive in a country considered more promising than their home country, even though in fact, they still have to live a hard life.

After Samba lost his uncle's ID card in a raid, Samba then changed his appearance for the second time after buying a new identity card. He changed his name to Modibo Diallo, and this time, Samba grew a moustache so that his face resembled the photo on ID card. Using Modibo Diallo's ID card, Samba managed to work again. However, the next problem was the personal conflict that arose between Samba and Jonas, a political refugee from Congo he happened to meet at the quarantine house. Samba and Jonas exchanged jackets with their ID cards in them, and when Jonas was drowned with Samba's ID 
card, Samba changed his identity once again to someone else. This time, with an official residence permit, Samba became Jonas, a political refugee from Congo.

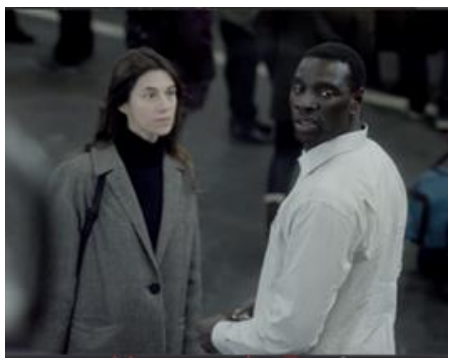

Figure 1 Original but fake ID (Samba, 2015) 01:51:14,663 --> 01:51:16,028

Alice : Tu as oublié ca.

Samba : Je ne peux pas faire ça. Je ne peux pas.

Alice : Qu'est-ce que ca change, maintenant? Tu la mérite pas? Prends-la. Pour toi, pas pour moi.

Samba : Alice, je sais mais comment je me prends?J'ai peur un jour d'oublier qui je suis.

Alice : Moi, je n'oublierai certainement pas. Si un jour tu oublie, crie ton prenom. Tout le monde pensera que tu as envie de danser.

Alice : You forgot this.

Samba : I can not do that. I can't.

Alice : This changes what, now? You think you don't deserve this? Use this. For you, not for me.

Samba : Alice, I know but how will I deal with this? I'm afraid that one day I forget who I am.

Alice : I certainly won't forget. If one day forget just scream your name. Everyone will think you want to dance.

The excerpt in Figure $\mathbf{1}$ above is a conversation between Alice and Samba just before the end of the movie. Alice handed over Jonas's ID card kept in the jacket which was entrusted to Alice. Alice was Samba's close friend whom he knew as a volunteer officer at the NGO office dealing with immigrants. At first, Samba did not want to take Jonas's identity and planned to return to Senegal with his uncle, Lamouna. Samba did not want to change his identity. He did not want to forget his own name and his origin. Alice assured Samba that she, as one of his closest friends, would not forget who Samba was. She also suggested that if one day Samba forgot his identity, Samba should shout his name: Samba! a name taken from a type of dance from Brazil. When Samba shouted his name, the people around him would not be suspicious and would think Samba was wanting to dance.

Another character who was also negotiating the cultural identity to survive is Walid a.k.a Wilson. Walid became Samba's friend after they both met at the mayor's office and together searched for a job at the labour bureau. Walid/Wilson was an undocumented migrant from Algeria who claimed to be a Brazilian to have more opportunities to work professionally and to get the love of a woman in France.

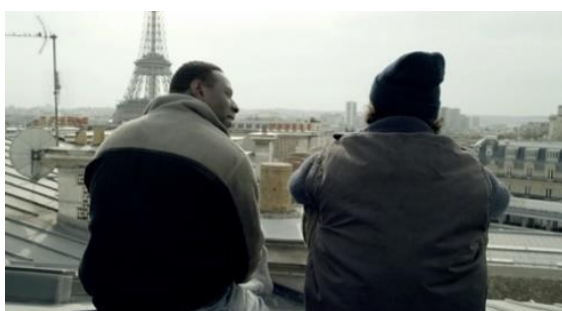

Figure 2 Arab-Brazil (Samba, 2015)

01:23:28,308 --> 01:24:21,970

Samba : Dites moi un truc...C'est quoi la capitale du Brésil pour toi?

Wilson : Alger.

Samba : C'est ça je me disais.

Wilson : En fait, je m'appelle Walid. Je suis né à Oran.

Samba : Pourquoi "Wilson"?

Wilson : Quand je suis arrivé à Paris, je galérais je galérais. Je suis tombé sur un groupe de brésiliens, sans papiers. Et je me suis rendu compte que pour le boulot, les nanas ... tout. Tout est plus simple quand je dis que je suis brésilien. Alors, je suis devenu Wilson.

Samba : Tu caches mieux.

Wilson :Pourquoi?

Samba : Tu es mon premier copain arabe brésilien mélangé.

Wilson : Par contre, tu dis rien, oui?

Samba : Tudo bem

Samba : Tell me something ... Just between us, which is the capital of Brazil?

Wlison : Algiers.

Samba : Well, as I suspected.

Wilson : Actually, my name is Walid. I was born in Oran.

Samba : Why Wilson?

Wilson : When I got here, stray too. I met a group of Brazilian, illegal. And I realized that to work, the flirt ... everything. Everything is easier when you speak Brazilian. So, I became Wilson.

Samba : I was thrilled.

Wilson : Why?

Samba : You are my first Arab friend mixed with Brazilian.

Wilson : But do not tell anyone.

Samba : It's all right (in Portuguese)

The excerpt above is a conversation between Samba and Walid/Wilson after they escaped from the police chase with the help of a female Arab/Maghreb descent domestic helper. Initially, Walid always spoke French with a Portuguese accent, claiming to have come from Brazil. However, when they were cornered, Walid spoke Arabic to an Arab/Maghreb descent domestic helper. Walid begged for help to escape from the police chase. When Samba heard Walid speak Arabic, Samba 
suspected that Walid was not a Brazilian. Samba asked what the capital city of Brazil was to Walid, and he answered, 'Alger". The capital city of Brazil should be Brasília. Then Walid admitted that he came from Oran, a city in Algeria. Walid also confessed that he changed his name to Wilson because he had met immigrants without official letters from Brazil who were easier to find work and in dealing with women. Walid then changed his name to Wilson and inserted Portuguese along with Brazilian accents and gestures while communicating.

Wierzbicka [16] argues that language imposes cultural boundaries on its users. In other words, the mastery of a language will also adopt ways of thinking, styles, and norms of behaviour, as well as ways of expressing feelings in the language. Consequently, the natural acquisition of a second language involves the inclusion of a person in the second culture. Thus, using a language does not only mean the assimilation of the linguistic code but also imply "being" a member of a particular cultural group and participating in various social interactions in the style of the culture from which the language originated. Often, a person's identity is enriched and redefined through this process. The use of language in daily interpersonal interactions is closely related to identity at the personal, cultural, and ethnic levels [17].

Since language and other aspects of culture (lifestyle, attitudes, beliefs, customs, and values) are interrelated phenomena, the acquisition of first language or mother tongue, second language learned after the first language and so on during migration will have behavioural consequences on each individual. This may involve changes in lifestyle (including daily practices and behaviour), self-representation, and self-construction [18]. The language and culture acquisition is experienced by Walid or Wilson. By learning Portuguese as his third language (Arabic is his mother tongue and French is the second language), Walid also adapts the styles and behaviour stored in the language and of course imitates the behaviour shown by the Brazilian people he knows. In this case, Walid is represented not only by having one cultural identity as an Algerian but also by being French and Brazilian through cultural negotiations. Walid's bicultural identity, Algerian-Arab, is later expanded to become an Algerian-French-Brazilian.

To be accepted by the French society, Walid has to continue to negotiate his bicultural identity not only through the process of acquiring the language from the colonial state but also by adopting the lifestyle manifested by the colonial state. The appearance of the subject of decolonization is not only physically presented in France and French movies but also has become an integral part of it. Legal identification as a Frenchspeaking citizen does not end with the recognition as a citizen but to prove the cultural differences within the same state system. This legalization has destabilized the identity formation process as conceptualized by the French Republic. The debate on French identity is related to the integration of the national identity with the question ["what does it mean to be French?"], and this was launched on October 25, 2009 by Eric Besson, the Minister of Immigration. It is an explicit warning to 'save' French identity from the "outsiders" or Muslim Maghrebi [19].

The identity narrative construction of Beur initially tells Walid's attachment to French national memory and his root in the Maghreb. It is important to understand the desire to be heard displayed by Beur cinéma. The narrative identity links the individual memory of Beur then to the collective memory. The traces are kept unforgettable and irreversible. A narrative function is constitutive of the experience of individual's 'selfhood'. Thus, it is important in the case of Beur and other postcolonial subjects who have gone through similar experiences in survival measure to mimic. This is one concept in the post-colonialism imitating what the colonial subjects do.

This scene seems to show that in order to "become" French, the cultural identity of the migrants must be abandoned. Migrants or immigrants must adopt the style of the people in the destination country or someone else, not only the language but also the style of clothing, ways of thinking, and even behaviour. Living with more than one culture is the solution to this assimilation. A bicultural identity is a solution as captured in this movie. The solution to various problems ranging from the issue of residence permits, the right to obtain a place to live and a job, and the state of being accepted in local communities are represented through continuous negotiation of one's identity instead of violent solutions as shown in other movies about migrants living in the suburbs of Paris.

\section{CONCLUSION}

This study found that the diaspora issues among the immigrants in the movie are represented by the difficult life experiences. This is not only about obtaining permission or legality as newcomers to the destination country but also in adapting to the new language and daily habits. It is even difficult for immigrants to interact with neighbors and the closest community. This movie portrays a situation that immigrants are ordinary citizens who experience the same ups and downs in their daily lives the same as the native French and other citizens of the world. 'Samba' has made a significant contribution to movie industries regarding social problems in France. This movie has successfully brought up the life problems and racism issues of the immigrants and looked closely at the lives of immigrants who are previously considered as the outsiders to become ordinary people living with daily problems. The success of this movie has been proven by many awards and reviews. 
'Samba' can be considered as a measure to integrate and live with failures with the least possible desire to make destruction. The desire to destroy is usually shown by resisting the pressure of the host country and the western lifestyle. Instead, the effort can be carried out by relying on the spirit to live and on the fighting spirit to succeed. The strong desires to study culture and increase knowledge to establish oneself to live in France specially to negotiate to become French without denying the original cultural roots are messages conveyed by 'Samba'. Cultural differences are not a block or an inhibiting wall to show love. Continuous efforts to narrow down intercultural gaps are the basis for making a new individual through various cultural negotiations. The flexibility of immigrants in negotiating their cultural identities has become a cultural asset that helps them survive and improve the standard of life when in other countries. Through Beur cinéma, immigrants and their descendants have a place to voice their existence as part of the society. Maybe, someday, Beur cinéma will become a genre in French movies occupying the same rank as the mainstream movies. Living as citizens with two (or even three) identities must be done by the migrants in order to survive in the destination country.

\section{ACKNOWLEDGMENTS}

Financial support for this study was provided by a grant from Ministry of Finance and Ministry of Education and Culture under the LPDP scholarship program namely the Indonesia Lecturer Excellence Scholarship (BUDI). I wish to express my deep gratitude to Professor Faruk and Budi Irawanto, Ph.D, my research supervisors, for their patient guidance, enthusiastic encouragement and useful critiques of this research work.

\section{REFERENCES}

[1] J. Desai, Beyond Bollywood: the cultural politics of South Asian diasporic film. New York: Routledge, 2004.

[2] Y. Long, F. Quan, and Y. Zheng, "Effects of Bicultural Identity Integration and National Identity on COVID-19-Related Anxiety Among Ethnic Minority College Students: The Mediation Role of Power Values," PRBM, vol. 14, pp. 239249, Feb. 2021, doi: 10.2147/PRBM.S294547.

[3] M. Hron, Translating pain: immigrant suffering in literature and culture. Toronto: University of Toronto Press, 2009.

[4] L. Aptekar and D. Stöcklin, "Children in Particularly Difficult Circumtances," in Handbook of Cross-cultural Psychology: Basic processes and human development, vol. 2, J. W. Berry, T. S. Saraswathi, P. R. Dasen, Y. H. Poortinga, and J. Pandey, Eds. Boston: Allyn and Bacon, 1997, pp. $377-412$.

[5] T. Kirszbaum, Y. Brinbaum, and P. Simon, "The Children of Immigrants in France: The emergence of a second generation," 2009, pp. 1-64. Accessed: Feb. 09, 2021. [Online]. Available: https://www.unicef-irc.org/publications/574-thechildren-of-immigrants-in-france-the-emergenceof-a-second-generation.html

[6] C. Bosséno, "Immigrant cinema: national cinema - the case of beur film," in Popular European Cinema, 1st ed., R. Dyer and G Vincendeau, Eds. London; New York: Routledge, 1992, pp. 51-62. doi: 10.4324/9780203388624.

[7] W. Higbee, "Re-presenting the urban periphery: Maghrebi-French filmmaking and the banlieue film," Cinéaste, vol. 33, no. 1, pp. 38-43, Jan. 2007, [Online]. Available: https://www.researchgate.net/publication/294667 151_Re-

presenting_the_urban_periphery_MaghrebiFrench_filmmaking_and_the_banlieue_film

[8] W. Higbee, "Diasporic and Postcolonial Cinema in France from the 1990s to the Present," in A Companion to Contemporary French Cinema, John Wiley \& Sons, Ltd, 2014, pp. 136-159. doi: 10.1002/9781118585405.ch6.

[9] Y. Laayouni, "Redefining Beur Cinema: Constituting Subjectivity through Film," Ph.D dissertation, University of Pittsburgh, Pennsylvania, 2012. Accessed: Feb. 09, 2021. [Online]. Available: http://dscholarship.pitt.edu/11446/

[10] K. Budiman, "Merambah Wacana Diaspora: Pulang itu Apa? Wacana Naratif Kaum Eksil," in Gerak Kuasa: Politik Wacana, Identitas, dan Ruang/Waktu dalam Bingkai Kajian Budaya dan Media, Jakarta: Kepustakaan Gramedia Utama, 2020, pp. 131-150.

[11] E. Y. Erten, P. van den Berg, and F. J. Weissing, "Acculturation orientations affect the evolution of a multicultural society," Nat Commun, vol. 9, no. 1, p. 58, Jan. 2018, doi: 10.1038/s41467-01702513-0.

[12] M. Chand and R. L. Tung, "Bicultural identity and economic engagement: An exploratory study of the Indian diaspora in North America," Asia Pac J Manag, vol. 31, no. 3, pp. 763-788, Sep. 2014, doi: 10.1007/s10490-014-9375-y.

[13] L. J. Cabassa, "Measuring Acculturation: Where We Are and Where We Need to Go," Hispanic Journal of Behavioral Sciences, vol. 25, no. 2, pp. 127-146, May 2003, doi: 10.1177/0739986303025002001.

[14] T. Wu, "Bicultural Identity," in Encyclopedia of Child Behavior and Development, S. Goldstein and J. A. Naglieri, Eds. Boston, MA: Springer US, 2011, pp. 238-239. doi: 10.1007/978-0-38779061-9_331.

[15] S. J. Schwartz and J. B. Unger, "Biculturalism and Context: What Is Biculturalism, and When Is It Adaptive?," HDE, vol. 53, no. 1, pp. 26-32, 2010, doi: $10.1159 / 000268137$. 
[16] A. Wierzbicka, Understanding cultures through their key words: English, Russian, Polish, German, and Japanese. New York: Oxford University Press, 1997.

[17] T. Hirsch and O. Kayam, "Academic Mothers' Definitions of Bilingualism, Bilinguality, and Family Language Policies," Psychology of Language and Communication, vol. 24, no. 1, pp. 22-43, 2020, doi: http://dx.doi.org/10.2478/plc2020-0002.

[18] J. Park, V. Norasakkunkit, and Y. Kashima, "Cross-Cultural Comparison of Self-Construal and Well-Being between Japan and South Korea: The Role of Self-Focused and Other-Focused Relational Selves," Front. Psychol., vol. 8, 2017, doi: 10.3389/fpsyg.2017.01516.

[19] M. Borkert and R. Penninx, "Policymaking In The Field Of Migration And Integration In Europe: An Introduction," in Migration Policymaking in Europe, 2011, pp. 7-20. doi: $10.1515 / 9789048515165-001$. 